\title{
Husum by, Svavsted borg og det nordfrisiske marked i 1504
}

\section{Af Bjørn Poulsen}

Hovedhandelsåren i senmiddelalderens Sønderjylland var den nordsydgående »oksevej«. ${ }^{1}$ Til denne sluttede sig imidlertid andre linjer, hvoraf der førtes varestrømme mellem øst og vest. I det følgende diskuteres nogle af de væsentlige forskelle $\mathrm{i}$ handelsruternes varesammensætning.

Det er målet med undersøgelserne at se, om det var de samme varer, i samme forholdsmæssige kvantiteter, som førtes af de forskellige handelsveje. Det skal vise sig, at dette langtfra var tilfældet. Vore kilder, der navnlig udgøres af toldregnskaber, viser, at der var stor forskel mellem handelsruterne. De demonstrerer eksistensen af forskellige samtidige typer af vareomsætning. Og de kaster lys over Sønderjyllands opdeling i områder med vidt forskellig økonomisk grundlag.

Endnu ved vi kun lidt om handelen i hertugdømmet Slesvig ved år 1500. Der var flere former - den internationale handel, bymarkeder, lokalhandelen. Blandt de handlende skimter vi storkøbmænd, der opererede med betydelige kapitaler over store strækninger, til tider over hele Nordeuropa. Mere begrænsede i deres handelsradius var derimod ofte andre handelsmænd - adelige, kræmmere og bønder. Det må nu understreges, at et usædvanligt handelsengagement ofte ses hos vestkystens storbønder.

Ønsker vi at sammenligne toldregnskaber ved år 1500, og på denne måde belyse sønderjysk økonomi, er vore muligheder begrænsede. Fra det vestlige Slesvig har tilfældet imidlertid overleveret os et par samtidige toldregnskaber.

Vort geografiske udgangspunkt bliver den nordfrisiske vestkyst med flækken Husum og bispeborgen Svavsted. Fra begge disse steder er der bevaret toldregnskaber, der optegner den trafik, som passerede ved år 1500. Husumregnskaberne er ført af byens tolder, og er bevaret for årene 1496-97 og 1504-6 (-1507?). Fra Svavsted eksisterer kun et toldregnskab, ført af borgskriveren Ludolph Eckhorst. Det findes sammen med de øvrige lensregnskaber for Svavsted, og dækker perioden mellem 29/9 1504 og 1/8 1505. Kombinationen af Husums og Svavsteds 


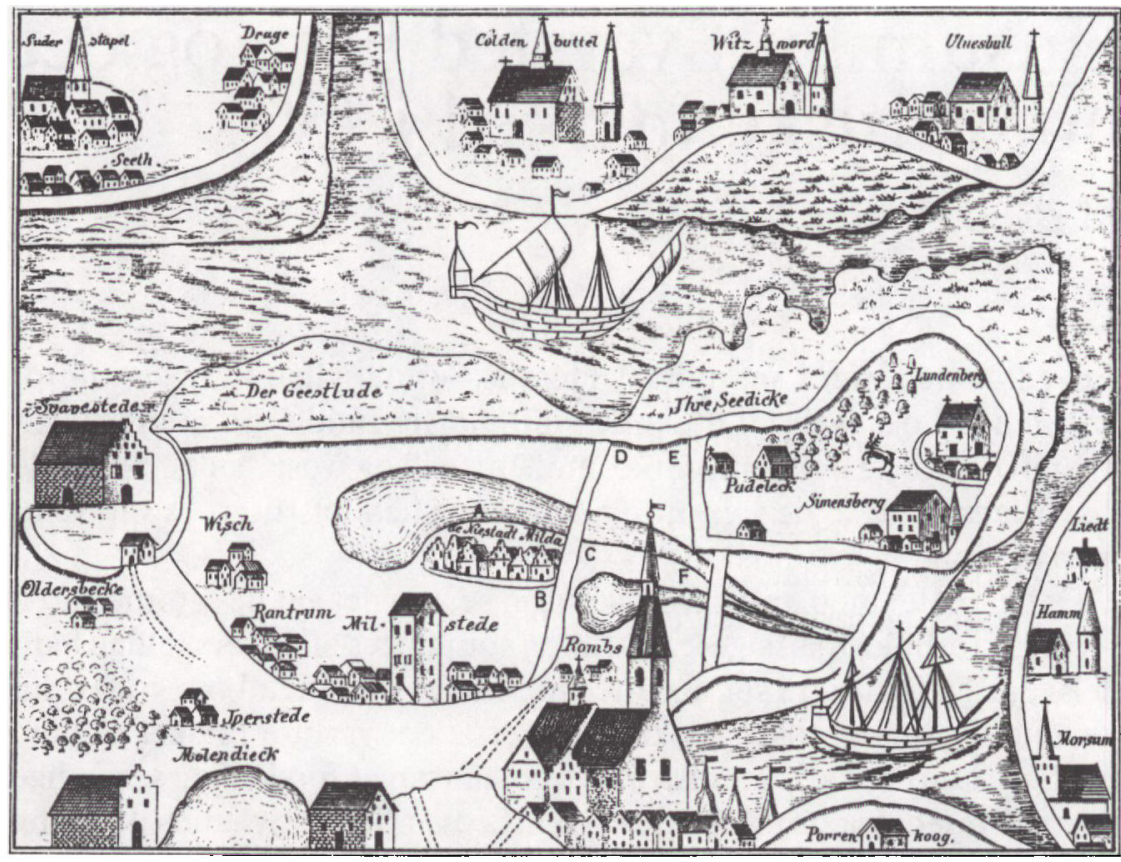

Kort fra 1588, tegnet af Iven Knudsen fra Vobbenbol. Det viser situationen for indvindingen af Damkog 1489. Til venstre ses Svavsted by, nederst Husum store kirke.

toldregnskaber giver os et indblik $\mathrm{i}$ handelslivet $\mathrm{i}$ byen og ved borgen $\mathrm{i}$ året $1504 / 5 .^{2}$

\section{Husum og Svavsted}

Husum var ved år 1500 en ekspanderende stad, der fortjener navn af by, selv om den ikke havde byrettigheder.

I 1438 lå på dens plads tre bebyggelser - Husum, Nordhusum og Østerhusum - med henholdsvis 109, 105 og 35 skatteydere, skønsmæssigt svarende til ialt 1250-1750 indbyggere. 1540 var antallet af husbesiddere i Husum o. 476. Indbyggertallet kan da vel sættes til omkring 2500-3000 indbyggere. Samtidig med, at byens befolkningstal fordobledes, blev det koncentreret på en enkelt bebyggelse. I 1540 var Nordhusum på kun 22 husstande, Østerhusum på 14. ${ }^{3}$

Der byggedes på fuld kraft. Allerede 1494 indviedes et franciskanerkloster. Bykirken, viet til Jomfru Marie, var midt i store ombygninger. 
$1506 / 7$ stod det store, dominerende kirketårn færdigt. Over 20 altre var at se inde $\mathrm{i}$ bygningen.

Om borgernes indstilling til brug af kapital fortæller en vedtægt fra 1504. Først $\mathrm{i}$ januar dette år samledes kirkeværger, »rekenslude« og oldermænd fra alle gilder i Husum i nærværelse af herredsfogeden for Sønder Gøs herreds, Walke Widdesen. De fastsatte en række bestemmelser: Når en moder kort efter fødslen sendte sit barn i kirke, måtte kun seks kvinder følge med. Når kvinden selv efter 6 uger blev »indladt« i kirken, skulle hun kun have følge af seks andre kvinder. Når byens gildebrødre og søstre mødtes en gang om året, skulle alle ofre samme beløb. Når brudepar gik til kirke om mandagen, så skulle brudgommen intet ofre. Bruden derimod måtte give 3 skilling til præsten ved højalteret. Det samme var tilfældet for bisidderne og de fire jomfruer, der gik forrest. ${ }^{5}$

Ikke religiøs pragtudfoldelse, men købmandsskab, stod for Husum-

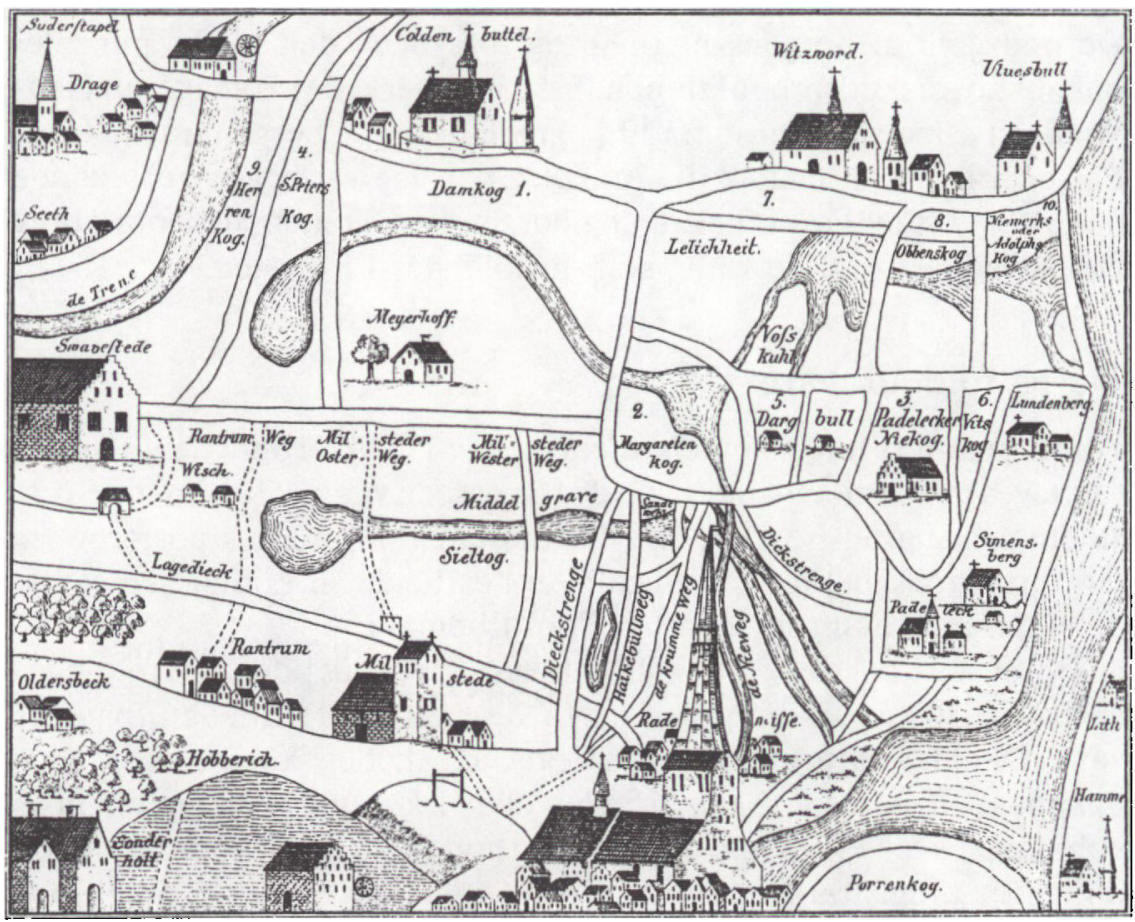

Kort fra 1588, hvor Iven Knudsen har tegnet området omkring Husum, som det sd ud pd hans tid efter de store inddigninger. 
borgerne som kapitalens rette anvendelse. Herpå beroede byens velstand. Borgen Svavsteds rigdom var derimod bygget på godsdrift.

Til borgen betaltes landgilde og afgifter i rug, havre, byg, strå, tagrør, høns, gæs og smør fra et stort antal fæstere, herunder hele sognet Svavsted. De samme bønder leverede yderligere rug- og havretiende. Hertil kom en række pengeafgifter - »svinepenge«, »bondeskat «, »vogn-

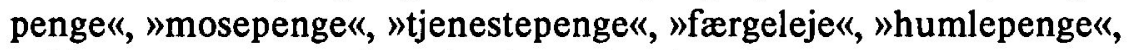
»oldenpenge «, "arneskat (rockpenninge), »oksepenge

Alle disse leverancer medførte, at borgens husholdning i stor udstrækning var selvforsynende. Inden for det biskoppelige godsområde kunne de fleste af de produkter hentes, som savnedes på Svavsted. Fra landsbyen Fysing, nord for Slesvig, kom således havre, og træ huggedes ved Treja. ${ }^{6}$ Svavsted borg var i sig selv en større bedrift med slotsfoged, knægte, håndværkere, mejerist og betydelige særmarker. Også et teglværk lå til borgen. Omkring den samledes flækken Svavsted med o. 50 husstande. Flækken udøvede en vis markedsfunktion over for den nærmere omegn. Her var flere håndværkere end $\mathrm{i}$ de øvrige landsbyer - bagere, smede, klejnsmede, skræddere, skomagere og tømrere. De nød godt af borgens nærhed, og forsynede den med varer eller opkøbte overskudsproduktionen. I 1505 erhvervede skomageren Hans Sondach således huderne fra 10 slagtede okser på borgen, mens Hans Fisker solgte 500 fladfisk til borgkøkkenet. De var begge bosiddende nede i Svavsted. Forbi flækken og borgen flød Trenen, der formentlig bar hovedparten af de varer, som fortoldedes i Svavsted.

\section{De fortoldede varer}

For nærmere at følge handelsvejene ved år 1500 skal der i det følgende foretages en gennemgang af alle de fortoldede varer i Husum- og Svavstedregnskaberne fra 1504/5. Til sammenligning sættes posterne fra Gottorpregnskabet for år 1501, som er bearbejdet af Lothar Schwetlik, og på visse punkter revideret af Poul Enemark.'

Til en start må det gøres klart, at visse varer gik uden om toldregnskabet. I Husum fik borgerne i 1487 bekræftet toldfriheden for egne varer. Det blev naturligvis understreget, at friheden ikke gjaldt for gods opkøbt til fremmede handelsfæller eller i kommission for udenbys købmænd. Men vi må regne med, at en god del af byens fødevareforsyninger er uregistrerede. Husums toldfrihed var ganske parallel med gejstlighedens og ridderskabets rettigheder: varer, der kun var beregnet til eget behov, og ikke til videre handel, skulle ikke fortoldes. I told- 


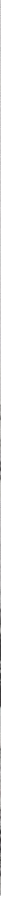

Kirken i Svavsted (Den slesvigske Samling ved Dansk Centralbibliotek for Sydslesvig).

regnskaberne mangler også den handel, som toldens indehaver selv stod for. Hverken bispens indkøb til Svavsted eller hertug Frederiks transaktioner i korn og kvæg kan altså spores i disse kilder. ${ }^{8}$

\section{Kvagavlens og husdyrholdets produkter (tabel 1)}

Vi får med al ønskelig tydelighed fastslået, at Husum som fortoldningssted ikke var på de store oksehandleres budget. Antallet af fortoldede okser er over hundrede gange flere i Gottorp end i Husum. Og så udviser Husum-tallene endda en betydelig stigning fra 1497, hvor kun 94 okser blev registreret. Det er sandsynligt, at de 249 okser, der førtes til Husum i 1504, overvejende var beregnet for byens eget forbrug. De personer, der fortoldede de små drifter til byen, normalt på 2-3 okser, var vel for en del omegnens bønder.

Husumregnskabets enkelte poster er ikke daterede, men dog sikkert indført løbende i kronologisk rækkefølge. Vi făr derfor ved f.eks. en tideling af samtlige poster i regnskabet en mulighed for en grov årstids- 
Tabel 1 Kvægprodukter

\begin{tabular}{|c|c|c|c|}
\hline mot & Husum 1504 & Svavsted $1504 / 5$ & Gottorp 1501 \\
\hline heste & 226 & 49 & 4427 \\
\hline foler & 36 & 2 & \\
\hline føl & & 2 & \\
\hline okser & 249 & 51 & 28.418 \\
\hline køer & 101 & 26 & 2 \\
\hline umgkvæg & 39 & 36 & \\
\hline kalve & 6 & & \\
\hline smør & $94 \frac{1}{2} \mathrm{td}$ & $271 / 2$ & $261 \frac{1}{2} \mathrm{td}$ \\
\hline ost & & 1 & \\
\hline svin & 69 & 164 & 951 \\
\hline făr & 322 & 4 & 748 \\
\hline lam & 280 & 15 & 601 \\
\hline kød & $1 \mathrm{td}$ & $1 \mathrm{td}$ & \\
\hline fedt & $13 \mathrm{td}$ & & \\
\hline køkkenfedt & $1 \frac{1}{2} \mathrm{td}$ & & \\
\hline spæk & $1 / 2$ skippd & 1 uspec.post & 46 »side , 4 skippd \\
\hline talg & $2 \mathrm{td}$ & & \\
\hline huder & $37 \frac{1}{2}$ deger ${ }^{1}$ & 1 kurv & 290 stk \\
\hline skind & & 1 degen, 1 uspec. & 1145 stk,12 skindmese ${ }^{2}$ \\
\hline kalveskind & 53 deger $^{1}$ & 2 uspec.poster & 240 stk \\
\hline "rotlasch $\ll^{3}$ & & & $350 \mathrm{stk}$ \\
\hline "smaschen ${ }^{4}$ & & & 20 stk \\
\hline "semes"s & $2 \mathrm{td}$ & & \\
\hline făreskind & 172 deger $^{1}$ & 1 uspec.post & \\
\hline lammeskind & & & 1 "tymmer $\iota^{6}$ \\
\hline$\overline{\text { fjer }}$ & $\begin{array}{l}2^{1 / 2} \text { stuck }^{7} \\
5 \text { sække } \\
1 \text { uspec.post }\end{array}$ & $\begin{array}{l}2 \text { stuck }^{7} \\
2 \text { uspec.poster }^{2}\end{array}$ & \\
\hline
\end{tabular}
1) degen $=0.10$ stk
2) pakke med skind
3) rødgarvet læder
4) lammeskind med krollet uld
5) "vaskeskind "
6) mængdemål for skind, $40-60$ stk
7) stuck = mængdemål

fordeling af varegrupperne. Således er oksernes antal inden for de enkelte 10 dele:

\begin{tabular}{lrrrrrrrrrr} 
tiendedel & 1 & 2 & 3 & 4 & 5 & 6 & 7 & 8 & 9 & 10 \\
\hline antal okser & 0 & 28 & 13 & 14 & 7 & 12 & 45 & 63 & 20 & 47
\end{tabular}


Oksedrifterne til Husum var tilsyneladende, selv om der var en vis koncentration om foråret og om efteråret, nogenlunde jæunt fordelt over hele året.

De 51 okser, der fortoldedes i Svavsted, kan vel repræsentere dyr på vej mod bymarkeder som Husum. Forsyninger til bybefolkningen leveret fra omegnen var formentlig også de køer og det ungkvæg, der registreres i Husum og i Svavsted. At disse poster næsten fuldstændigt glimrer ved deres fravær i Gottorpregnskabet viser, at der ikke var tale om eksportvarer, men om direkte lokale forbrug.

Nogen rolle som eksportør af levende kvæg havde Husum ikke.' Dette indtryk forstærkes, hvis vi ser på svin, får og lam, der i Gottorp var eksportvarer af en vis betydning. Transporten af småkvæg til Husum har uden tvivl kunnet forbruges i selve byen, og blev vel overvejende leveret af de omliggende marskenge. I 1505-toldregnskabet fra Husum fortolder således fem gange »en ditmarsker«. Ditmarskernes varer bestod af ialt 10 okser, 8 stk. ungkvæg, $3 / 4$ td smør og 4 får. Ankommet til Husum blev kvæget opkøbt af slagtere, og solgt på ugentlige markeder i hele, halve og kvarte stykker. ${ }^{10}$

I Svavsted er grund til at hæfte sig ved de relativt mange fortoldede svin. De repræsenterer givetvis forsyninger overført fra skovlandet $\mathbf{i}$ øst og på geesten til marskegnene. Både i Husum og Svavsted er svinetransporterne næsten udelukkende koncentreret $\mathrm{i}$ årets sidste del, dvs. i november/december.

I modsætning til studene kunne forarbejdede kvægprodukter indskibes. Dette bliver tydeligt ved en betragtning af toldposterne smør, fedt, skind og huder. Der er næppe tvivl om, at disse varers mængde i Husum skyldtes en eksport vestpå pr skib. Smørret ankom til byen fra talrige mindre producenter, som f.eks. en ditmarsker, der 1504 fortoldede $1 / 2$ tønde smør. De produkter, der blev ud af det slagtede kvæg, var derimod, som senere skal omtales, nogle få storkøbmænds varer.

Blandt de mange heste, der fortoldedes, skjuler sig en vis import af avlsdyr fra Frisland. Men ellers udgjorde hestene en udpræget eksportvare." Udførelsen over Gottorp dominerede, men også Husum og Svavsted kunne mønstre relativt betydelige tal. Der er givetvis overvejende tale om heste opdrættet i marskegnene. ${ }^{12}$ Dyrene kom til Husum i små flokke, oftest endda kun en enkelt ad gangen:

$\begin{array}{llllllllllllll}\text { antal heste } & 1 & 2 & 3 & 4 & 5 & 6 & 7 & 8 & 9 & 10 & 11 & 12 & 13\end{array}$

$\begin{array}{llllllllllllll}\text { antal drifter } & 37 & 10 & 6 & 1 & 3 & 2 & 2 & 3 & 1 & 0 & 1 & 2 & 2\end{array}$


Til byen hentedes dyrene bl.a. fra Tønderegnen, som registreringen af »en mand fra Tønder Husumborgernes hestehandel sig. I Ribe-toldregnskaberne fra 1500tallets første år fortolder flere »fra Husum«. I 1506 forekommer på Ribemarkedet tre Husumborgere med henholdsvis 4, 2 og en hest. ${ }^{13}$ Ofte kom hestene dog til Husum fra det nærmeste opland. Fragtmanden (de vorman) fra Hatsted, en halv snes $\mathrm{km}$. nord for Husum, bragte 11 foler til byen. I Husums toldregnskab for året 1506 træffer vi »en mand fra Eidersted « med en fole, og i et udateret regnskab fra ca. 1507 forekommer »en mand fra Vis herred « med 3 heste. For en dels vedkommende købtes hestene op af Husumborgere. En professionel kvæghandler fra Husum var Jon Paisen, der 1504 fortoldede 30 heste i sin hjemby. Han træffes $i$ de følgende år med stude- og oksedrifter $i$ Ribe, Husum og Gottorp. ${ }^{14}$ Hestehandler, så han fik navn deraf, var Hinrich Pferdekoper, der i det udaterede Husumregnskab fortolder 10 heste. $^{15}$

En del af de heste, der indkom til Husum, forblev vel i byen til borgernes brug. Størstedelen blev dog rimeligvis sendt videre. Illustrativ for retningen af eksporten er »en mand fra Zwolle«, der $1504 \mathrm{i}$ Husum fortoldede en hest, og »en vesterlandsk mand « med 3 heste $i$

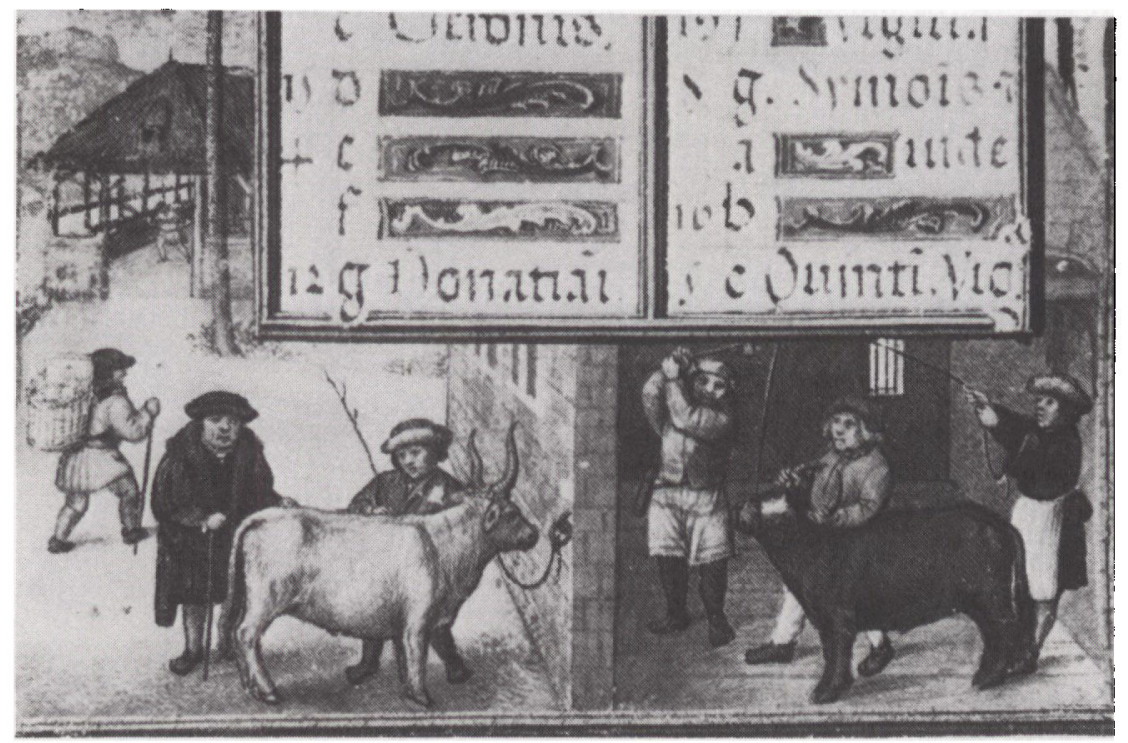

Oksehandel og okseslagtning. (Flandern 1500-50, München, Bayerisches Staatsbibliothek, cod.lat. 23637 fol. 5v. 
det udaterede Husumregnskab fra 0.1507 . Transporterne gik overvejende til Nederlandene, Flandern eller Frankrig; en del dog også til det nordtyske marked. ${ }^{16}$

\section{Korn og andre agerbrugsprodukter (tabel 2)}

Husums og Svavsteds stilling som gennemgangssteder for korntransporter træder klart frem. Korn fortoldedes overhovedet ikke i Gottorp.

Kornet ankom til Husum i mange småportioner, overvejende om efteråret. Byggens mængdefordeling, der er karakteristisk også for de andre kornsorter, ser således ud:

$\begin{array}{llllll}\text { antal tønder } 2-4 & 5-9 & 10-14 & 15-19 & 20-24 & 25-28\end{array}$

\begin{tabular}{lllllll}
\hline antal poster & 55 & 60 & 23 & 15 & 2 & 2
\end{tabular}

Dette billede står i markant modsætning til det indtryk, vi får af 1497toldregnskabet fra Husum. De kvantiteter, der dette år fortoldedes af byens tolder, var også afvigende i forhold til 1504; men det er tilsyneladende netop karakteristisk for Husumtolden i disse år, at kornmængderne varierede voldsomt fra regnskab til regnskab. Det virkelig bemærkelsesværdige er, at rugtolden i 1497 var fordelt på kun to poster,

Tabel 2 Korn etc.

\begin{tabular}{|c|c|c|c|}
\hline & Husum 1504 & Svavsted $1504 / 5$ & Gottorp 1501 \\
\hline byg & 1252 td & \multicolumn{2}{|c|}{$\begin{array}{l}372 \text { td, } 106 \text { td byg+ } \\
\text { rug }\end{array}$} \\
\hline havre & 1056 td & & \\
\hline rug & $264 \mathrm{td}$ & $\begin{array}{l}384 \text { td, } 2 \text { foder }{ }^{1} \\
106 \text { td byg og r }\end{array}$ & \\
\hline hvede & $194^{1 / 2}$ td & $51 \mathrm{td}$ & \\
\hline "korn" & 2 uspec.poster & & \\
\hline mel & & $12 \mathrm{td}$ & \\
\hline zrter & $5 \mathrm{td}$ & & \\
\hline humle & $59 \frac{1}{2}$ dromt $^{2}$ & 5 td & $\begin{array}{l}1124 \text { dromt, } 19 \text { sæk- } \\
\text { ke, } 39 \frac{1 / 2}{2} \text { foder }^{1}\end{array}$ \\
\hline hør & & & 2 fade, 3 skippund \\
\hline hamp & 10 skippd & 2 sække & 4 skippd \\
\hline reb & & & 4 dusin \\
\hline $\log$ & & & $23^{1 / 2}$ td, 2 vogne \\
\hline brød ${ }^{3}$ & & $17 \mathrm{td}$ & \\
\hline
\end{tabular}
1) vognlæs.
2) humlemål.
3) 3 td »weggeren «, 14 td »kockes . 
der tilsammen udgjorde en sum på 663 tønder (nemlig 11 store læster og 13 læster). De to poster med rug er ganske sikkert skibsladninger, som det senere skal vises. I 1504-tolden forekommer målet for skibsladninger, læster, kun to gange i forbindelse med rug (= 48 tønder). En forklaring på det radikale skift i toldregnskabets kornposter er da rimeligvis en administrativ omlægning fra fortoldning ved udskibning - til told opkrævet ved byporten af tilført korn. Hvis denne forklaring er rigtig, viser den, at de mange småproducenter og handlende førte korn til Husum, hvor det så blev opkøbt af storkøbmænd, der udskibede hele læster. Som konkret eksempel på bondeproducenternes korntilførsler til Husum kan tjene 27 tønder rug, der 5/3 1505 fortoldedes i Svavsted. Til disse er tilføjet: "Ditmarskerne kørte det til Husum «. ${ }^{17}$

Humle var i perioder en importvare af største betydning i Gottorp, særlig i krigsårene 1510-11. Det er i Gottorpregnskaberne tydeligt, at humleførere fra humlegårde i Mecklenburg-Schwerin og fra byen Kiel var vigtige eksportører. Husums humletilførsler kom givetvis også for størstedelen fra syd. I 1493 blev humlesalget i byen reguleret. Det bestemtes, at de fremmede humleførere med deres heste og vogn kun måtte sælge større partier humle, ikke under $1 / 2$ »drompt«. Det må dog pointeres, at der også blev dyrket humle i Slesvig, således i betydelig grad omkring Svavsted borg. Her var man selvforsynende, og enkelte sendinger kan udmærket være ført til Husum. ${ }^{18}$

\section{Fisk (tabel 3)}

Foruden korn har Husum og Svavsteds toldregnskaber en anden vare i mængder, der indicerer storhandel - fisk.

Tallene afslører, at en stadig lugt af fisk har ligget over havnen i

Tabel 3 Fisk

\begin{tabular}{llll} 
& Husum 1504 & Svavsted $1504 / 5$ & Gottorp 1501 \\
\hline sild & $123 \mathrm{td}$ & $34^{1 / 2}$ td & 22 td, 205 wall \\
\hline hvidling & 100.375 stk & 2 td & 42.770 stk \\
\hline torsk & 3 td & & \\
\hline fladfisk & 61.075 stk & & \\
\hline al & $11^{1 / 4}$ td & $60^{1 / 4}$ td & $5^{1 / 2}$ td \\
\hline laks & & & $1 / 2$ td \\
\hline tørfisk & & 4 stige $^{2}$ & 1 læst \\
\hline fisk & & 250 stk, $1 / 4$ td
\end{tabular}

1) 0.80 stk.

2) dvs. snese. 
Husum. De vigtigste fangstpladser var i Vadehavet og ved Helgoland. En del fiskedes fra Ejdersted. Lensmanden på Gottorp solgte således 1489/90 71/2 læster Ejdersted-sild til en købmand i Husum. Kildernes tale om "flandersk sild" vidner imidlertid også om transporter helt nede fra Nederlandene. ${ }^{19}$ De vigtigste fiskearter var den lille torsk hvidlingen, sild og skulden, en flynderfisk.

Tilførslerne til fiskemarkedet var naturligvis afhængige af fangsttiderne. Fordeles forekomsten af sild, hvidling og fladfisk inden for 10 dele af Husums toldregnskab fra 1504 fremkommer følgende billede:

\begin{tabular}{lcccccccccc} 
tiendedel & 1 & 2 & 3 & 4 & 5 & 6 & 7 & 8 & 9 & 10 \\
\hline td sild & $71 \frac{1}{2}$ & 5 & 4 & 16 & 0 & 3 & 1 & 0 & 1 & $211 / 2$ \\
\hline hvidling & 2500 & 2250 & 0 & 250 & 7625 & 60000 & 7250 & 2500 & 2000 & 16000 \\
\hline skuld & 0 & 0 & 0 & 2500 & 3200 & 5625 & 1750 & 0 & 0 & 48000 \\
\hline
\end{tabular}

Sildefangsten foregik, som det ses, i december/januar, mens fiskeriet af hvidling og fladfisk i højere grad skete i sommeren og efteråret. I almindelighed fortoldedes fisken i små poster; ud af ialt 31 toldbetalinger for skuld var de 30 på tusind stk. eller derunder, og ud af 45 gange fortoldede hvidling var de 33 tilfælde på eller under tusind stk. Samtidig forekom der så påfaldende store poster som 43.000 hvidlinge - eller 48.000 skuld.

Skibseksport af fisk finder vi dokumenteret i 1497-regnskabet for Husum, hvor to købmænd afskiber 42 tønder sild. I dette toldregnskab forekommer der herudover $65^{1 / 2}$ tønde sild fordelt på mindre poster, som i 1504. Bag de små toldposter kunne ligge salg til oplandet. Eksempler på dette finder vi i pengeregnskaberne for Svavsted 1504/5. Her noterer borgskriveren flere gange i marts, april og maj 1505, at fisk er købt ind i Husum til borgens behov. En gang sendte skriveren 8 skilling til Husum for at få købt 80 hvidlinge og 4 kabliau (torskefisk), en anden gang 1 rhinsk gylden til en »kipe« hvidling. Hyppigt dækker toldposterne i regnskabet vel imidlertid fisk, som er ladet på vogne, og sendt til købedygtige markeder længere borte. En god del af de sild og hvidling, der passerede Gottorp kom fra Husum. ${ }^{20}$

\section{Trae og tagrør (tabel 4)}

Træets fremtrædende plads i Svavstedtolden var betinget af toldstedets beliggenhed nær skov og eng og tæt op af Trenen. I Svavstedborgens pengeregnskab $1504 / 5$ ser vi talrige eksempler på, at en 3-4 mand 
Tabel 4 Træ og tagrør

\begin{tabular}{|c|c|}
\hline 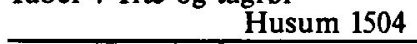 & Svavsted 1504/5 \\
\hline$\overline{\text { egetræx }}$ & $\begin{array}{c}89^{1 / 2} \text { foder, } 2 \text { »eck «, } \\
1 \text { foder »eck« }\end{array}$ \\
\hline $\begin{array}{l}\text { brændeved } \\
\text { (»berneholt } \ll \text { ) }\end{array}$ & $\begin{array}{l}309 \text { foder, } 3 \text { uspec.poster, } \\
1 \text { post blandet staver og } \\
\text { brændeved }\end{array}$ \\
\hline $\begin{array}{l}\text { stavetræ } \\
\text { ("stackholt«) }\end{array}$ & $\begin{array}{l}20 \text { foder }(=0.2050 \text { stk) } \\
50 \text { stk, } \\
1 \text { uspec. post }\end{array}$ \\
\hline $\begin{array}{l}\text { staver } \\
\text { ()stackes() }\end{array}$ & $\begin{array}{l}32 \text { foder } \\
1750 \text { stk, } \\
1 \text { uspec. post (= o.400 stk), } \\
\text { (ialt ca. } 5350 \text { stk) }\end{array}$ \\
\hline $\begin{array}{l}\text { lægter/rafter } \\
\text { (nslete })\end{array}$ & $\begin{array}{l}32 \text { foder, } 100 \text { stk } \\
\text { (ialt o. } 3300 \text { stk) }\end{array}$ \\
\hline $\begin{array}{l}\text { stokke } \\
\text { (nstok }(\text { ) }\end{array}$ & 2 stk, 1 uspec. post \\
\hline $\begin{array}{l}\text { ris } \\
\text { (nstickryße«) }\end{array}$ & 12 foder \\
\hline rør (»reytes & $11.250 \mathrm{stk}$ \\
\hline istagl & 500 stk \\
\hline $\begin{array}{l}\text { tagrør (?) } \\
\text { ("vladdack reytes () }\end{array}$ & $\begin{array}{l}1500 \text { stk, } \\
1 \text { uspec. post }\end{array}$ \\
\hline strå & 1 uspec. post \\
\hline vognhjul & 40 stk \\
\hline senge & 1 \\
\hline tomme tønder & 36 stk, 1 last \\
\hline $\mathrm{kipe}^{2}$ & $1,1 / 2$ foder \\
\hline
\end{tabular}

1) rør høstet på isen om vinteren.

2) store aflange kurve.

lønnes for en tur op ad Trenen til Treja efter træ. En del af borgens behov for rør dækkedes gennem 4 bønders pligtleverancer af 1500 rør. Køb kunne dog også være nødvendige. 13/4 1505 betalte borgskriveren på fogedens ordre 4 skilling for 100 »istag«. Sælgeren af disse rør, der høstedes med le om vinteren, når vandet frøs til is, var bonden Tymme Prawest fra Hude i Svavsted sogn. Udover sin ret store gård med rug- og havredyrkning, samt avl af okser og svin, drev Tymme Prawest en vis handel. 9/3 1505 afsatte han således for 1 mark seksten fiskekurve på Svavstedborgen. De folk, der handlede med træ og tagrør, var sikkert i almindelighed netop bønder som Tymme. Købere udgjorde utvivlsomt marskens beboere, men også, som en notits i Svavstedtoldregnskabet viser, folk helt fra Helgoland. Transporter fra det indre af landet til marsken ligger sandsynligvis på samme måde bag de $\mathbf{4 0}$ fortoldede vognhjul og de tomme tønder. 
Tabel 5 Skovprodukter etc

\begin{tabular}{|c|c|c|c|}
\hline 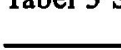 & Husum 1504 & Svavsted $1504 / 5$ & Gottorp 1501 \\
\hline honning & $30 \frac{3}{4} \mathrm{td}$ & & $1 / 2 t d$ \\
\hline voks & & & $\begin{array}{c}\text { 321/2lispund, } \\
5 \text { skippund, } \\
4 \text { pakker }\end{array}$ \\
\hline tjære & $8 \mathrm{td}$ & & \\
\hline beg & $7 \frac{1}{2} \mathrm{td}$ & & \\
\hline pelse & & & 127 stk \\
\hline nødder & $3 \mathrm{td}$ & & \\
\hline
\end{tabular}

Træ figurerer ikke i Gottorptoldregnskabet, hvilket ikke kan undre. Derimod kunne man vente det i Husum, da byens ældste toldtarif fra 1461 har ret detaljerede takster for træ. ${ }^{21}$ Men det træ, der førtes ind til Husum, har åbenbart kun været borgernes private tilførsler til eget behov, og således undtaget fortoldning.

\section{Produkter fra skov og overdrev (tabel 5)}

Det er øjensynligt, at honningeksporten har spillet en vis rolle fra Husum. I to tilfælde fortoldes store partier på $12 \mathrm{og} 18$ tønder, rimeligvis med henblik på udskibning.

\section{Tekstilerne (tabel 6)}

Det fine klæde (wand) af uld udgjorde en udpræget importartikel, vævet i Nederlandene og England. ${ }^{22}$ Gottorp-ruten var absolut førende $i$ indførelsen af denne vare; men Husum var også godt med. I stor udstrækning må det klæde, vi finder i Husum betragtes som returgods fra sejllads ned mod Hamburg/Nederlandene. ${ }^{23}$ Når det imidlertid nævnes i Husum-regnskabet fra 1504, at »en mand fra Ribe« fortolder 18 »laken«, er det vel muligt, at der her er tale om varer importeret over Ribe, der var førende i dansk klædeimport.

Ganske anderledes end med det finere klæde forholdt det sig med stoffet »webbe«/»wobbe«, der var groft og hjemmevævet. Som Poul Enemark har påvist, er der næppe tvivl om, at vi her har at gøre med et produkt, der er skabt i det nordfrisiske bondemiljø. ${ }^{24}$ I Husumregnskaberne fremgår dette klart af navnene på de folk, der fortolder »webbe«. De er overvejende typiske frisiske bondenavne. Bønderne førte deres "webbe« til Husum et enkelt eller to stykker ad gangen - $i$ et tilfælde fortoldedes $1 / 2$ stykke, i 38 et stykke, i et tilfælde $1 \frac{1}{2}$ stykke og i 12 til- 
Tabel 6 Tekstiler

\begin{tabular}{|c|c|c|c|}
\hline & Husum 1504 & Svavsted $1504 / 5$ & Gottorp $1501^{1}$ \\
\hline laken wandes ${ }^{2}$ & $123^{1 / 2}$ & 4 & 203 \\
\hline packen wandes & & & 6 \\
\hline packen laken & 1 & & 46 \\
\hline pakker & & & 44 \\
\hline terling ${ }^{3}$ laken & & & $1 / 2$ \\
\hline korsbånd $^{4}$ & & & 24 \\
\hline småpakker ${ }^{5}$ & & & 7 \\
\hline wand $^{2}$ & & 1 uspec.post & \\
\hline "kramlaken« & & $\begin{array}{l}1 \text { kurv med k. } \\
\text { og klæder }\end{array}$ & \\
\hline lærred & 2 stuck $^{6}$ & & 1900 stuck, 1 pakke \\
\hline "webbe« & 63 stuck $^{6}$ & 16 uspec.poster & 177 stuck, 4 stubch \\
\hline vadmel (»watman«) & & & 6 stuck $^{6}$ \\
\hline klæder (»klederen «) & & 2 td & \\
\hline
\end{tabular}

1) jfr Enemark, P: Studier, s. 169.

2) laken = størrelse på klæde ("wand")

3) pakker med 40-90 laken

4) pakker; kan også indeholde huder og skind

5) kan indeholde 9-18 laken

6) mængdemål

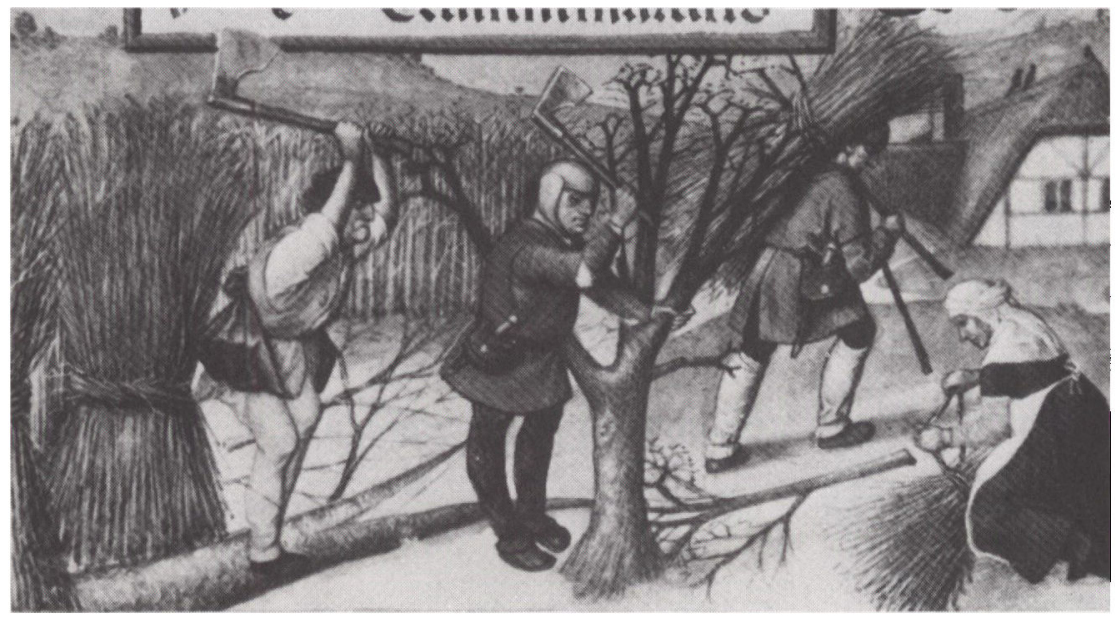

Der hugges ris til kurvefletning. (Flandern o. 1500, München, Bayerisches Staatsbibliothek, cod.lat. 8345 fol. 11 r. 
fælde 2 stykker. ${ }^{25}$. Samme handelsmønster udviser Husumregnskaberne fra de øvrige år omkring 1500, i 1497-regnskabet fortolder en mand ved navn Thames dog undtagelsesvis hele 40 stykker. Han må vistnok antages at være en professionel opkøber af bøndernes produkter.

\section{Saltet (tabel 7)}

Om det salt, der optræder i Gottorptoldregnskaberne, antager Lothar Schwetlik, at det uden undtagelse var Lüneborg-salt. Der blev dog også i Gottorp fortoldet frisisk salt på vej østover. ${ }^{26} \mathrm{Hvad}$ angår Husumtolden kan vi her adskille Lüneborgsaltet fra det øvrige salt. 8 tønder benævnes i regnskabet rent ud »luneborger solt«. De fortoldes til en sats af 4 penninge tønden, og til Lüneborgsaltet må da rimeligvis regnes 6 ubenævnte tønder salt, der går til samme sats. Det øvrige salt, $312 \frac{1}{4} \mathrm{td}$, fortoldes til et lavere beløb på 3 penninge. Der er i dette tilfælde utvivlsomt tale om det billigere hjemmeproducerede salt, udvundet af marskens tørvejord. Det samme gælder formentlig hovedparten af saltet i Svavsteds toldliste.

Ligesom vi kender det fra Ribe, kom frisersaltet for en stor del til Husum og Svavsted i efteråret. Typisk blev det fortoldet i småportioner, som tallene fra Husum viser:

\begin{tabular}{lccccccccccccc} 
antal tønder & 1 & 2 & $3+3 \frac{1}{2}$ & 4 & 5 & 6 & 7 & 8 & 9 & 10 & 12 & 14 & 16 \\
\hline antal poster & 22 & 21 & 20 & 7 & 6 & 1 & 5 & 2 & 1 & 1 & 6 & 1 & 1
\end{tabular}

Tabel 7 Salt

\begin{tabular}{llll} 
& Husum 1504 & Svavsted $1504 / 5$ & Gottorp 1501 \\
\hline salt & & $25 \mathrm{td}$ & $146 \mathrm{td}$ \\
\hline Lüneborg salt & $8 \mathrm{td}$ & & \\
\hline salt à 4 d/td & $6 \mathrm{td}$ & & \\
\hline salt à $3 \mathrm{~d} / \mathrm{td}$ & $312^{1 / 4} \mathrm{td}$ & & \\
\hline
\end{tabular}

\section{Drikkevarer, frugter og luksusvarer (tabel 8)}

Den største ølimport skete over Gottorp. En ganske betydelig indførsel af øl, navnlig fra Hamborgs bryggerier, gik dog også over Husum. ${ }^{27}$ En del kom formentlig til byen med hamborgske handlende - det tyder 
Tabel 8 Drikkevarer etc.

\begin{tabular}{|c|c|c|c|}
\hline & Husum 1504 & Svavsted $1504 / 5$ & Gottorp 1501 \\
\hline husum $\bullet 1$ & $21 \mathrm{td}$ & & \\
\hline mumme ${ }^{1}$ & 2 fade & & \\
\hline hamborg ol & $41 \mathrm{td}$ & 1 last, 5 td & \\
\hline bremer al & $14 \mathrm{td}$ & & \\
\hline einbeck ol & $1 \mathrm{fad}$ & & \\
\hline$\overline{\text { ol }}$ & (=ialt 76 td, 7 fade $)$ & & $152 \mathrm{td}, 24$ fade \\
\hline$\overline{\text { olie }}$ & & $1 / 2$ pipe $^{2}$ & $2 \frac{1}{2}$ pipe \\
\hline mjød & $4 \mathrm{td}$ & & $2 \mathrm{td}$ \\
\hline vin & $\begin{array}{c}26^{1 / 2} \text { ame }^{3} \\
1 \text { uspec. post }\end{array}$ & & 7 ame \\
\hline rosiner & 6 kurve & & \\
\hline sæbe & $3 \frac{1}{2}$ td & & $1 \mathrm{td}$ \\
\hline bøger & 2 kister & & \\
\hline
\end{tabular}

1) øl fra Braunschweig

2) langt smalt fad

3) tøndemål for vin

ihvertfald herpå, at en Dirick van Homborch fortoldede 5 tønder hamborgsk øl i 1504. I flere tilfælde dækker toldposterne i Husum over forsyninger, der transporteres hjem af forbrugere uden for byen. Dette gælder sikkert for de to tønder hamborgsk øl, som fortoldes af Arnt Kokemester, der var bosiddende i Flensborg og havde leverancer til slottet her. ${ }^{28}$ Husums ølimport blev solgt videre til kunder $i$ hele det øvrige Slesvig. $1489 \mathrm{k} ø$ bte lensmanden på Gottorp flere tønder bremer og hamborger $ø$ l fra Husum, og i Gottorp-tolden var Husumkøbmænd med hamborgøl ikke sjældne. ${ }^{29}$ Interessant er det, at Husum har haft en betydelig egenproduktion af $ø 1$, der er blevet afsat i omegnen. Som vinimportør var Husum Gottorp overlegen. Vinhandelen i byen varetoges hovedsagelig af nogle ganske få storkøbmænd, der tog vinen hjem som returgods ved sejllads på Nederlandene.

Af kulturhistorisk interesse er boghandelen. I 1504 fortoldede Herman van Emden 2 kister med bøger i Husum. Dette var en trafik, der fortsatte. 1505 kom Jasper Bokekoper med en kiste, 1506 Claus Bokevorer med endnu en. Der har åbenbart været et stadigt, omend lille, behov for litteratur i Husum by.

\section{Metaller og metalarbejder (tabel 9)}

Mens en del forarbejdet metal førtes forbi Gottorp, er fortoldningen i Husum domineret af råvarer, først og fremmest jernet fra de svenske 
Tabel 9 Metaller

\begin{tabular}{|c|c|c|}
\hline aoer y metaller & Svavsted $1504 / 5$ & Gottorp 1501 \\
\hline "osemund « & 11 fade & 9 fade \\
\hline stål & & $1 \mathrm{fad}$ \\
\hline$\overline{\text { bly }}$ & & $1 / 2$ skippd \\
\hline kobber & 1/2 skippd»gammelt «k. & \\
\hline kander/gryder & & 20 lispd, 11 skibspd \\
\hline kedler & & 9 stk, $1 / 2$ stuck $^{2}$ \\
\hline sværd & & 1 dusin \\
\hline
\end{tabular}

1) svensk jern

2) mængdemål

Tabel 10 Emballering etc.

\begin{tabular}{lccc} 
& Husum 1504 & Svavsted 1504/5 & Gottorp 1501 \\
\hline Kramfade & 9 & 1 & 162 \\
\hline fade & 22 & 20 & \\
\hline kramtønder & 6 & 1 & 123 \\
\hline "droge«tønder $^{1}$ & 10 & & 24 \\
\hline kasser $^{2}$ & 2 & 8 & 17 \\
\hline kramkurve & 4 & & \\
\hline kurve & 1 & 1 & 775 \\
\hline taske (»budel«) & & & 16 \\
\hline vogne & 26 & & 7 \\
\hline kærrer & 2 & & \\
\hline slæder & & 1 &
\end{tabular}

1) tønder med tørgods

2) »kramfatel«, »tafel«, »tafelitter« (=kasse med forskydelige hylder)

3) en pram (?)

brug, »osemund«. Der er næppe tvivl om, at der er tale om tilførsler, der skulle bruges af lokale håndværkere.

Sluttelig kan der gives en oversigt over de fortoldede emballeringsenheder og transportmidler. En stor del af fadene og tønderne kom sydfra og indeholdt kramgods, som krydderier, isenkram, stof og klæder, som det vises i tabel $10 .^{30}$

\section{Handelens niveauer}

Ved gennemgangen af de fortoldede varer er det blevet klart, at der i de slesvigske vareudvekslinger kan spores en række lag. 


\section{Oksevejen}

Den store internationale rute var vejen over syd til Gottorp. Her var der repræsenteret handelsmænd fra hele Jylland, fra Fyn, fra store dele af Nordtyskland, fra Nederlandene - foruden slesvigerne selv. Her blandedes de mange varer. Nordfra strømmede først og fremmest okser, okser og atter okser, men også heste var en betydelig handelsartikel. Lam, får, svin og smør spillede en vis rolle. Blandt det fra syd indførte gods kan særligt nævnes klæde, humle, salt og øl. Hertil kom allehånde kramgods. ${ }^{31}$

\section{$\emptyset$ st-vest-ruten over Husum}

På samme internationale niveau som Gottorp-vejen, befinder sig en række transaktioner, knyttet til Husums havn. De er på den ene side betinget af de farter, der udgik herfra mod syd-vest, på den anden side

Oksevejen syd for Slesvig omkring Sorgvold (Foto: Helge Krempin).

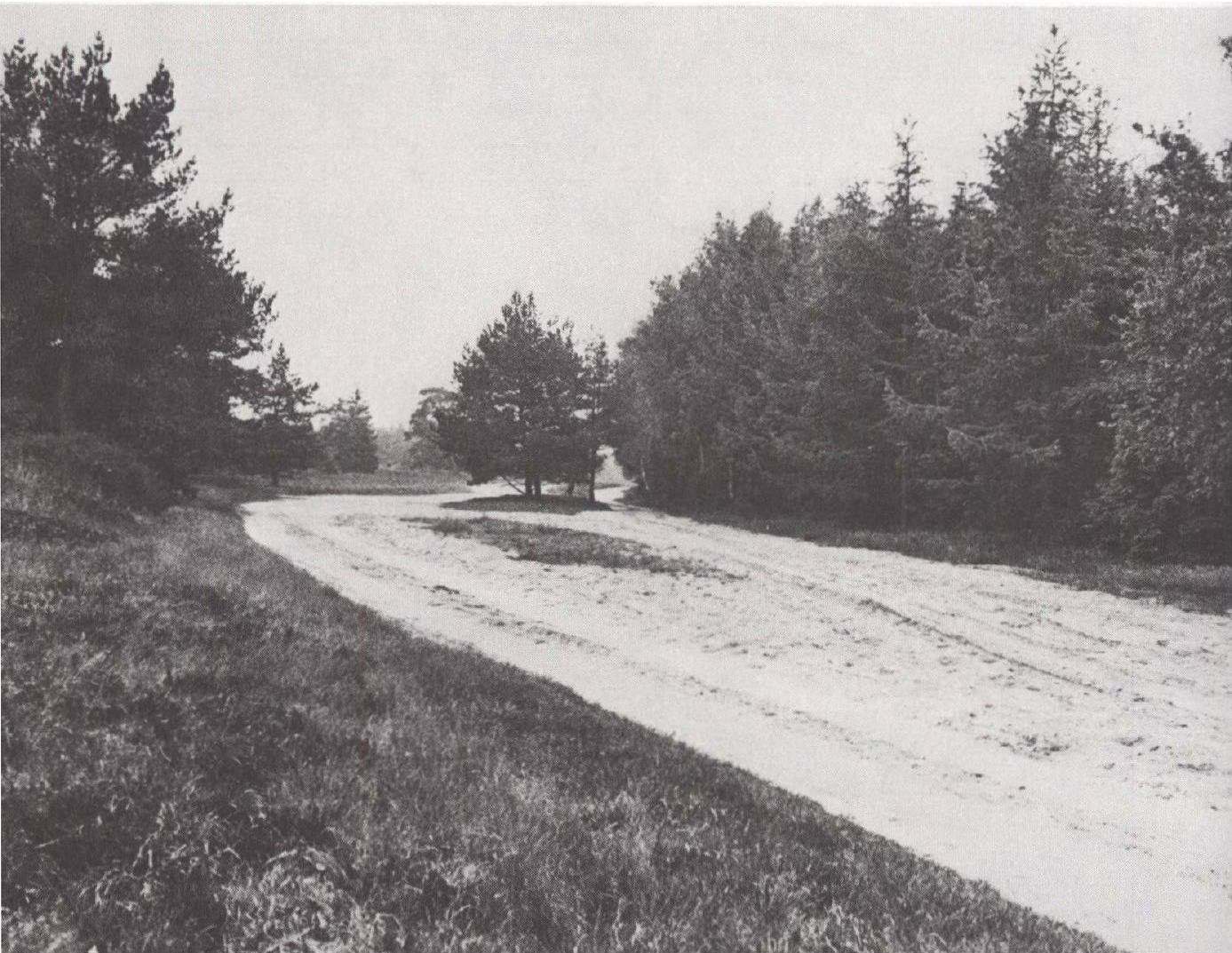


af landtransporter østover, navnlig til Flensborg og videre ind i Østersøen. ${ }^{32}$

Til belysning af, hvor stor en del af de varer, der fortoldedes i Husum, som indgik i denne transithandel, er byens toldregnskab fra 1497 af central betydning. Den sidste del af dette optager nemlig en liste - »De scippers im iaer xcvii«. Dette er en fortegnelse over, hvad en 7-8 købmænd har overgivet til skippere i 1497. Blandt befragterne træffer vi flensborgerne Hinric Holste og Hans Kistemaker, to af købmændene var åbenbart i kompagniskab - Sander og dennes »cumpan « Gert. At der er tale om udskibede varer fremgår ved en jævnføring af navnene i listen med den øvrige del af toldregnskabet. Ved en sådan modstilling af posterne for 3 flensborgske købmænd fremkommer resultatet i tabel 11.

Tabel 11

Husum told 1497

A. "skibsliste" B. normaltold

HINRIC HOLSTE:

30 deger fåreskind

32 deger skind

40 deger uld

$6 \mathrm{td}$ fedt

6 td spæk

1 td talg

5 td "semes" $"$

$1 / 2$ td sild

HANS KISTEMAKER

3 læster malt

3 lester sild

5 laster "tøndegods

1 skippund kobber

$3 / 4$ td sæbe

1 td tøfler (»patrinne«)

2 kurve rosiner

8 slaken"

pelsværk

2 heste

1 skimmel

1 td salt

$3 / 4$ td sæbe

6 ame vin

$1 / 2$ pipe olie

12 "laken"

2 "droge« $\mathrm{td}^{2}$

LAURENS TUCHSEN

2 skind

2 deger huder

$1 / 4$ td sæbe

1 last "semes "

1) "vaskeskind"

2) "tørgods $i$ tønder

Der er næppe tvivl om, at varerne $i$ »skibslisten « repræsenterer sendinger på vej mod vest, mens toldregnskabets almindelige poster er returgodset, indkøbt på rejsen.

Der er allerede gjort opmærksom på, at man sandsynligvis i 1497 kun fortoldede det udskibede korn. For visse andre varer ser det imidlertid 
ud til, at en sammenstilling af toldregnskabet og "skibslisten « kan give et indtryk af forholdet mellem ordinære tilførsler til byen, og eksportvarer videre vestpå. Det gælder f.eks. skind. I alt nævnes i hele toldregnskabet 167 deger, 2 sække, 4 stk skind, samt 127 deger, 600 stk fåreskind. Heraf blev der udskibet 62 deger, 2 stk skind og 50 deger, 600 stk fåreskind. Formentlig blev da ihvertfald omtrent halvdelen af de skind, der optræder, udført pr. skib. For hudernes vedkommende blev 2 deger sendt med skib, mens $11^{1} / 2$ forblev i Husum by. Alt fedt, talg, voks og pelsværk, samt det meste spæk, blev øjensynligt lastet i skibe. Af sildene udførtes 42 tønder som skibslast, $65 \frac{1}{2}$ tønder fortoldedes almindeligt. Skibenes importvarer var primært »laken«, vin, øl fra Bremen og Einbeck, men også sæbe, rosiner etc.

På samme måde som i 1497-regnskabet viser det sig, at man i de følgende Husumtoldregnskaber kan finde poster, der må udgøre eksport og import af søvejen. Vi kan tage to eksempler fra 1504-tolden som vist $i$ tabel 12.

Tabel 12

Husum told 1504

SEVERIN SCHOMAKER
A. 24 deger oksehuder
40 deger kalveskind
B. 28 »laken«
$1 \frac{1}{2}$ td køkkenfedt
18 td honning
3 »droge td $^{\text {9 }}$
1 ame vin
$1 / 2$ td sæbe
2 »droge $\ll \operatorname{td}^{1}$

JOCHUM TILE

A. 8 læster rug

150 deger făreskind

12 deger kalveskind

1 last fedt

1 td kød

3 td nødder

1 mlaken"

1) »tørgods« i tønder

Går vi nu tilbage til 1497-regnskabet fra Husum, får vi klart demonstreret, hvordan købmændene overgav deres last til skiftende Husumskippere. Hinric Holste f.eks. benyttede i årets $1 ø b$ følgende skippere: 1) Heyne Westuelinck, 2) Hinric Westuelinck, 3) Webbeman, 4) Lange Dirick, 5) Hinric Molen. Den anden side af sagen, nemlig at en skipper ofte havde last for adskillige, fremgår ligeledes af regnskabet.

Mere detaljerede oplysninger om selve sejlladsen fra Husums havn får vi gennem tre regnskaber, som Benedikt von Ahlefeldt aflagde i 1497, 1498 og $1499 .{ }^{33}$ De belyser hertug Frederik I's fragtsejllads med 
flere skibe fra Husum, bl.a. med en kogge. Ialt fragtede hertugen 1497 172 læster, $21 \mathrm{td}$ havre, $31 \mathrm{td}$ byg, $18 \mathrm{td}$ hvede. Om hans kogges lasteevne fortæller det, at den hertugelige part på to rejser i 1497 androg henholdsvis 51 og 481/2 læster. Men langt over halvdelen af den samlede fragt var andres eje, som der betaltes fragtpenge af. De fremmede befragtere bestod dels af borgere, dels også i enkelte tilfælde af adelige, bl.a. lensmanden på Gottorp, Hinrich Blome, der lod fragte korn og huder. På hertugens kogge var besætningen, ud over den befuldmægtigede Benedikt von Ahlefeldt, skipperen, styrmanden, en skriver, 7 sømænd, en kok og en bødker ("putker ) med svend. ${ }^{34}$ Lasterne, der overvejende bestod af korn, afsattes i Nederlandene. 1499 solgtes til Isbrant Gertsen og Adrian Clawes i Harlem henholdsvis $10 \mathrm{og} 24$ last havre, en tredje Harlem-købmand købte $25^{1 / 2}$ last havre, i Amsterdam solgtes $25 \frac{1}{2}$ last havre til tre købmænd. Returvarerne udgjordes af klæde, heste, - og bl.a. kanoner. År 1500 fik hertugen kvittering på 3 kartover, som klokkestøberen i Kampen, Gert van Won, havde støbt. ${ }^{35}$

Den hertugelige handel må i dimensioner have ligget på linje med, eller muligvis endda overskygget de private købmænds. Men selve grundprincippet bag handelen - eksport af korn og forarbejdede kvægprodukter til Nederlandene, og import af luksusvarer herfra - var ens for hertug og købmænd. Kun ejendomsforholdet til skibene afveg. For de privatejede fartøjer var det sikkert reglen, at ejerskabet var delt mellem flere. I 1470'erne besad således en Ribe-borger $1 / 8$ i en Husumevert. ${ }^{36}$

I Husums toldregnskab fra 1504 finder vi flere udenbys storkøbmænd. Rådmanden i Slesvig Merten Bruggeman importerede 9 tønder hamborgsk $ø$, og kieleren Gotke Langenborg afsendte $2 \frac{1}{2}$ deger huder samt 1 td talg. ${ }^{37}$ De købmænd, der eksporterede over Husums havn var dog, som det allerede er berørt, ud over Husumborgerne selv, navnlig flensborgere.

Husumborgerne foretog formentlig kornopkøb delvis med kapital fra Amsterdam, som vi kender det allerede $1464 .{ }^{38}$ I byen opererede udenlandske købmænd, "gæster « - i 1504-toldregnskabet fra Husum nævnes skipperen Lange Dirichs gæst, der importerede et større parti vin. Der er imidlertid næppe tvivl om, at den virkelig store kapital til søhandelen præsteredes fra Flensborg, selv om Husumborgerne efterhånden tog over. I 1504-regnskabet optræder kun enkelte flensborgere, som fortoldere af korn, således rådmanden Brun Buckeberch med 74 tønder byg, 2 tønder hvede, 10 tønder havre. Ofte er derimod flensborgske købmænd udelukkende noteret for import af luksusartikler. 


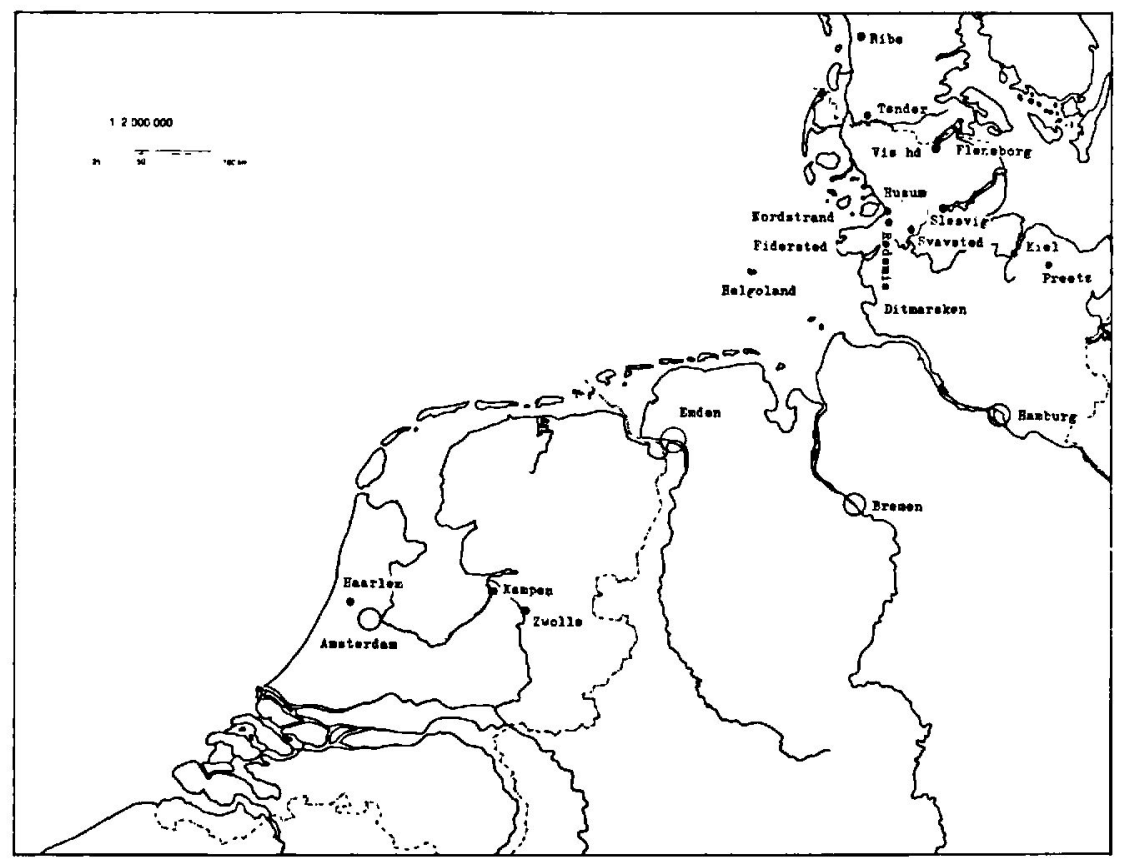

Husums handelsforbindelser omkring år 1500.

Storkøbmanden Michel Risenberg betalte told af 6 ame vin, 4 tønder bremerøl, 1 fad Einbeck-øl. Vi kan formentlig gå ud fra, at vi i et tilfælde som dette, kun har den ene side af fragtregnskabet. Holder vi os til Michel Risenberg, ses det, at han i 1511 fik udførselstilladelse wat han må udføre her af riget og vestværts« 10 læster korn, 8 læster smør, sild og andre fødevarer. En sådan eksport hang snævert sammen med import af luksusartikler, som det fremgår af endnu en tilladelse, Risenberg fik i 1511. Samtidig med, at udførslen af $1 \frac{1}{2}$ læster korn, smør og bast bevilgedes, blev der givet indførselstilladelse til humle, salt, salpeter, vin, øl etc. Der er næppe tvivl om, at Risenbergs udskibning i Husum år 1504 også har bestået af korn. ${ }^{39}$

Udskibningen fra Husum var utvivlsomt hovedbetingelsen for byens rigdom ved år 1500 . For storkøbmanden stod udførslen som den ene grundpille i regnskabet. Den anden var woksevejen« sydover. Husums og Flensborgs købmænd forenede i deres forretninger de to handelsveje. L. Schwetlik har talt op, at Husumborgere i 1491 over Gottorp drev 887 okser, mens flensborgere fortoldede 2034. Det førstnævnte af de breve, der gav flensborgeren Michel Risenberg tilladelse 
til udskibning, bevilgede ham lige så karakteristisk retten til, at "uddrive på foråret « 150 okser. I det ovenfor anførte toldregnskab fra Gottorp år 1501 betalte han told af 147 okser. $^{40}$

\section{Det nordfrisiske lokalmarked}

På et lavere niveau end de store ruter, men bestemt ikke betydningsløst, tegner der sig et billede af udvekslinger ved og omkring Husum.

Mange af Husumtoldregnskabets poster belyser selve byens forsyning. En stor del af det kvæg, der førtes til byen fortæredes her, leverancer af korn og fisk var yderligere grundlag for borgernes næring. "Webbe« blev vel benyttet til borgernes klædninger. Forsyningerne kom, som vi har set, fra det nordfrisiske landskab, bl.a. fra Ejdersted, samt fra Ditmarsken. Vi kan sjældent identificere bondeleverandørerne; men de større gårde har naturligvis været førende i udvekslingerne. I enkelte tilfælde kan vi dog komme sælgerne af dagligdagsvarer lidt nærmere. Det er f.eks. tilfældet med Claus Ploch (eller Pluck). Han fortoldede i 1504-regnskabet følgende varer af fem gange:

1) 12 tønder byg, 1 tønde hvede.

2) 2 heste, 2 okser, 250 skuld.

3) 9 køer.

4) 1 istuck webbe«, $1 / 4$ tønde smør.

5) To kvarte tønder smør.

En lignende varesammensætning står Claus Ploch for i de følgende års toldregnskaber, og der synes på forhånd at være grund til at tro, at han havde nære relationer til omegnens landbrug. At Ploch var husejer i Husum, er der ikke tvivl om. År 1500 nævnes hans hus i »Norderstraten « i Husum, og samme år havde han her indkvarteret 9 landsknægte på vej ud i det skæbnesvangre felttog til Ditmarsken. Igen 1516 hører man om Claus Plochs hus i Husum. 1525-26-28-31 træffer vi ham imidlertid uden for byen, nemlig som bispens foged i Rødemis. Vi kan formode, at der bag de fortoldede poster i 1504 ligger enten en egenproduktion, eller salg for bispen af de indkomne indtægter i fogediet. ${ }^{41}$

I toldregnskaberne fra Husum afspejler sig ikke kun fødevareleverancer, men også indkøb af råvarer, der formentlig skulle forarbejdes i byen. Tydeligt er dette således for to personer med tilnavnet smed, der fortolder det svenske jern, osemund:

1) Claus Smyt (2 fade osemund).

2) Hans Smyt (1 fad osemund, 6 td havre, 4 td byg). 
I produktionen af tovværk skulle uden tvivl det skippund hamp benyttes, som Hynrick Repsleger (rebslager) betalte told for. En gruppe, der skiller sig ud som importører af korn, har tilnavnet bager, og er det vel også. I 1504 fortolder:

1) Hynrick Becker (2 td honning).

2) Hans Becker (4 td hvede, 2 td rug, 14 td malt).

3) Laurens Becker (4 td havre).

4) Peter Becker (2 $\frac{1}{2}$ td hvede, 3 td havre, 8 td malt).

5) Merten Becker ( 4 td hvede).

Eksemplerne kunne forøges med flere fra de øvrige års toldregnskaber, nævnes skal dog blot Peter Kapersleger (kobbersmed), der 1506 fortoldede 1 skippund kobber i Husum.

Ganske sikkert lader det sig ikke bevise, at der i de nævnte tilfælde er tale om håndværkere bosiddende i Husum; men det er dog en rimelig antagelse. Hvis det forholder sig således, betyder det, at der blev lagt told på produkter, som indførtes af borgere til videreforarbejdning.

På det lokale niveau skete der også en eksport fra Husum. Der var tildels tale om distribution af allerede indførte varer. Fra Svavstedborgen købte man således 1504/5 små partier havre af Husums købmænd. Fisk solgtes til større forbrugere i omegnen og længere væk. Allerede 1452 købte lensmanden i Flensborg, foruden ærter og øl, 12 tønder sild i Husum, 1454 erhvervede provsten i det holstenske kloster Preetz smør og 8 tønder sild i byen, og 1489/90 købte lensmanden på Gottorp »skuld" her. Aftager af de importerede luksusartikler var på samme måde storhusholdningerne. For Gottorp slot indkøbtes i Husum rosiner, mandler og bønner $1489 / 90$, og til Svavsted blev der $1504 / 5$ bl.a. købt olie..2

Også visse forarbejdede produkter blev afsat i omegnen. Det bedste eksempel herpå er Husum-øllet. De 21 tønder øl, der nævnes i toldregnskabet 1504 , kan kun betragtes som salgsvarer på vej til lokale forbrugere. Byens øl var gængs vare ude i landsbyerne, således blev Rødemis' beboere 0.1510 beskænket med Husum- $\emptyset 1$, hvis de da betalte deres landgilde til bispen. ${ }^{4}$ Til salget af håndværksprodukter sluttede sig præstationen af serviceydelser for oplandet. I Svavstedregnskabet fra 1504/5 forekommer flere eksempler herpå. To gange sendte borgskriveren havre til Husum for at få det malet til gryn. En skrædder fra Husum tjente 24 skilling ved at arbejde på Svavstedborgen, og en tømrer og dennes svend lønnedes med 2 gylden for $4 \frac{1}{2}$ dags arbejde - 
Husum by, Svavsted borg og det nordfrisiske marked i 1504

59

mesteren fik 4 skilling pr dag, svenden 2 skilling. En vis arbejdsdeling mellem by og land havde åbenbart sat sig igennem i Nordfrisland.

Mellem geest og marsk

Den lokale arbejdsdeling kom imidlertid ikke kun til udtryk i forholdet mellem by og land. Også de regionale forskelle og specialiseringer træder frem i kildematerialet.

Belysende herfor er toldregnskabet fra Svavsted 1504/5. Svavsteds

peter fosth istols bith mole.

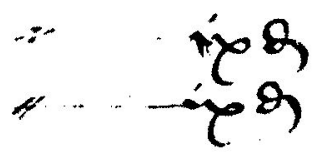

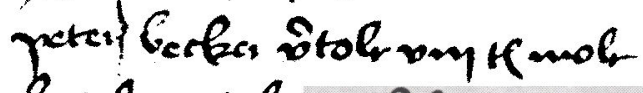

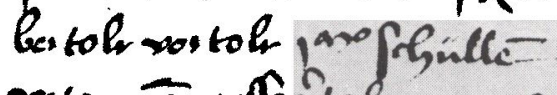

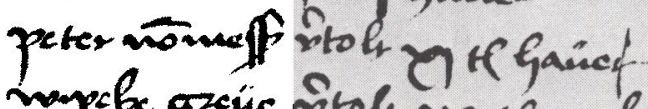
- if * $\quad$ if mapefe geñe stoh ye tc molr.

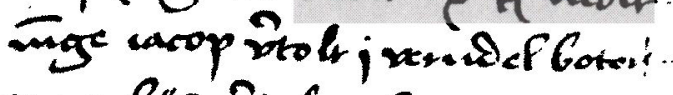
zemer bxip ôtol, for

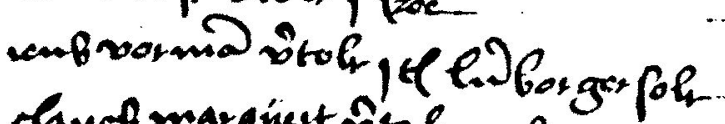

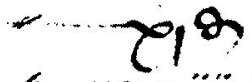
" taings

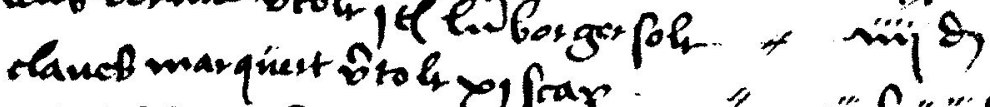

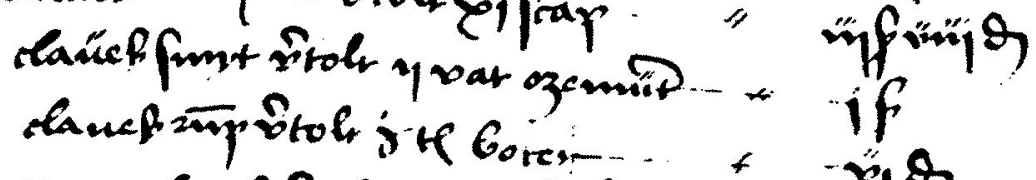

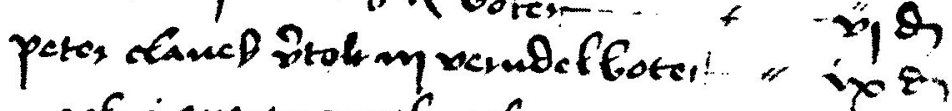

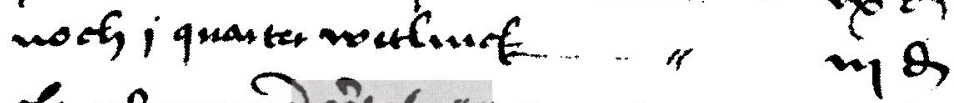

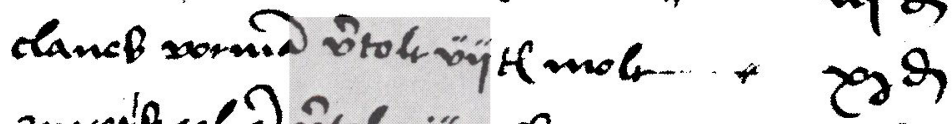

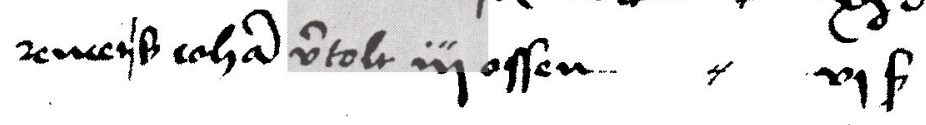

En side fra Husumtoldregnskabet 1504 (Rigsarkivet). 
toldsted var beliggende på kanten mellem geestens morænelandskab og den flade marsk. Med næsten nødvendighed kom de udvekslinger i stand, som vi ser i toldregnskabet. Træ og træprodukter som vognhjul og tomme tønder sendtes i stort tal ud i marskengene. Svin, der havde gået på olden inde $\mathrm{i}$ landet, transporteredes samme vej. En ret betydelig fortoldning af ål skal vel også omfattes som et led i dette mønster.

Marskegnene havde i almindelighed et stort behov for træ. Sendinger heraf fra den skovrige geest og østlandet til marsken havde utvivlsomt $\mathrm{i}$ århundreder fundet sted langs hele den nordfrisiske kyst. Nord for vort undersøgelsesområde var Ribe storeksportør af tømmer hentet i skovene ved Kolding og Vejle. Da træeksport fra Ribe i 1480 blev forbudt, undtoges udtrykkeligt vesterhavsøerne og marskegnene. ${ }^{44}$

Til gengæld for de varer, der kom fra øst, havde friserne traditionelt leveret heste, "webbe«, hjemmebrændt salt og smør. Friservogne lastede med de tre sidstnævnte produkter rullede østover til markedsdagene i Rendsborg, Kiel og Ekernførde, som Poul Enemark har vist det ud fra Gottorps toldregnskaber for $1485 \mathrm{og}$ følgende år. ${ }^{45}$ Disse tilførsler fra frisiske bønder lader sig også vel fornemme i toldregnskaberne fra Svavsted og Husum. En hyppig følgevare til friserprodukterne er i øvrigt i Husum fjer.

Det var imidlertid næppe disse varer, produceret for det lokale og regionale marked, som tegnede den frisiske storbondes økonomi ved år 1500. En god del af de træleverancer, der førtes til marskegnene, og som registreredes i Svavsted, gik uden tvivl til de store digebyggerier, der fandt sted ved denne tid. ${ }^{46}$ Inddigningerne signalerer klart den vægt, som marskbonden nu lagde på produktion af korn og kvæg. Afsætningen heraf blev grundlaget for hans rigdom. Et lag af rige bønder opstod; i deres rækker taltes herredsfogeden i Sønder Gos herred, Walke Widdesen, hvis lange række af jorderhvervelser netop i årtierne omkring 1500 vi kan følge ud fra hans egne notater. ${ }^{47}$

\section{Det nordfrisiske - og det større marked}

Fælles for Svavsted og Husum var beliggenheden på geestranden, tæt ved marsken. Dette sikrede de to bebyggelser en lokalt og regionalt bestemt handel med udveksling af fødevarer og håndværksprodukter, træ etc.

Disse udvekslinger er sikkert typiske for større dele af Sønderjylland. Landsdelens regionale opdeling i østland, geest og marsk har fra gammel tid befordret vareudvekslingen. 
Den lokale økonomi var på den anden side ved år 1500 tæt bundet til transaktioner på det overregionale plan.

Nederlandenes byer voksede, korn var nødvendigt her. Overalt i Europa steg behovet for kød. Både Husum og Svavsted blev da naturligt gennemgangssteder for tilførsler til de tætbefolkede og købedygtige egne nede i Europa. En del af den produktion de formidlede var korn, dyrket i de tilgrænsende marskområder. Om det alene var den lokale produktion, der dannede basis for kornudførslen, kan diskuteres. Korn transporteret over Flensborg fra Østersølandene, navnlig Polen, kan have spillet en rolle. Men der er næppe tvivl om, at der bag de store kornudførelser fra Husum lå en øget markedsproduktion hos marskbønderne.

Hvor Svavsteds kornposter kan tegne den udførsel, der fandt sted fra hele vestkysten ned mod det større marked, var Husum exceptionel. Den vækst, som vi oplever her i disse år - bl.a. med bygningen af en af Danmarks største kirker - blev mulig ved intense forbindelser med navnlig Nederlandene. I disse handelstransaktioner indgik et bredt spektrum af varer, først og fremmest kornet.

Husums havn nød derimod kun i mindre grad godt af den anden specialiseringsgren inden for det nordfrisiske landbrug, kvægavlen. Selv om en del forarbejdede kvægprodukter udskibedes, var og blev det landevejene, som ledte okserne sydover, således som det afspejles i Gottorps toldregnskaber.

Det er vigtigt at fastholde, at de oksetransporter, som har været genstand for så megen opmærksomhed i historieforskningen ikke altid var afgørende for det sønderjyske økonomiske liv. Hvad angår handelen på vestkysten og storbyen Husums trivsel, synes andre varer, bl.a. kornet, at have været centrale.

\section{NOTER OG HENVISNINGER}

1. Becker-Christensen, H: Hærvejen i Sønderjylland. Ábenrå 1981.

Enemark, P: Oksehandelens historie ca. 1300-1700. Særtryk af - Sortbroget Kvæg baggrund og udvikling i Danmark. 1983.

Samme: Studier i toldregnskabsmateriale. I-II, Århus 1971.

Jürgens, A: Zur Schleswig-Holsteinischen Handelsgeschichte des 16. und 17. Jahrhunderts. Berlin 1914.

Matthiesen, H: Hærvejen. En tusindårig vej fra Viborg til Dannevirke. (4. udg.), Kbh. 1951.

Schwetlik, L: Der Gottorp passierende hansisch-dänische Handel und seine Träger 1484-1519. I-II, Z Sch-H Gesch 85/86, 1961 (s. 61-130), 88, 1963 (s. 93-174). 
Wiese, H: Der Rinderhandel im nordwesteuropäischen Küstengebiet vom 15. Jarh. bis zum Beginn des 19. Jahrh. Quellen und Forschungen zur Agrargesch. XIV, 1966 (s. 1-110).

2. Rark, Sønderj. fyrsteark. Hertug Frederik - Husum toldregnskab 1496, 97, $1504,5,6$, udat.

La Sch, Abth. 162, Schwabstedt Amtsrechnungen, 1504.

3. Panten, A: Die Hauswirte Husums im Jahre 1438. Familienurkundliches Jahrbuch Schleswig-Holstein. 20, 1981 (s. 5-12).

Tyvende Penninge Skat af Husum 1540, SJy Sk Jb (s. 327-333).

Ved ansættelse af befolkningstal er benyttet den gangse multiplikator - jfr. Lorenzen-Schmidt, K-J: Die Sozial- und Wirtschaftsstruktur schleswig-holsteinischer Landesstädte zwischen 1500 und 1550. Quell Forsch, 76, 1970 (s. 28).

4. Weber, H m.fl:: Die Kunstdenkmäler der Provinz Schleswig-Holstein. Kreis Husum. Berlin 1939 (s. $100 \mathrm{ff}$ ).

Beccau, C. V.: Versuch einer urkundlichen Darstellung der Geschichte Husums. Schleswig 1854.

Voß, M: Aus dem vorreformatorischen Husum. Die Heimat, 9 Jg., 1899, (s. 113-116, 134-143).

Riese, G: Märkte und Stadtentwicklung am nordfriesischen Geestrand. Schriften des Geogr. Instituts der Univ. Kiel. X,4. 1940.

5. Da Gl Kbst Lovg, I (s. 84, 85), jfr Repert II, 11907.

6. Svavsted sogn -

Deisting, H: Die Verteilung des Landbesitzes im Kirchspiel Schwabstedt in alter Zeit. Mitt. des Nordfriesischen Vereins. $1908 / 9$ (s. 13-44).

Meyer, H: Schwabstedt. 5000 Jahre Schwabstedter Geschichte. Schwabstedt 1968.

7. Note 1 anf.arb. Schwetlik og Enemark, P: Studier

8. Da Gl Kbst Lovg, I (s. 82). Om toldfritagelse, toldsvig og smugleri - note 1 anf.arb. Enemark, P: Studier (s. 200-13).

9. Okserne omgik senere ofte Husum-tolden - note 1 anf arb Jürgens (s. 145).

10. Da Gl Kbst Lovg I (s. 86) - om kvægmarkedet i Husum.

Henningsen, J: Die Husumer Viehmärkte. (Manus., Stadtarchiv Husum).

11. Enemark, P: Hestehandel. KultHist Leks, 6 (sp 524-32).

12. Andresen, L: Zur Geschichte des Viehhandels im Amte Tondern. Nordschleswig 1924 (s. 163-75, 203-19).

13. Christensen, W: Dronning Christines Hofholdningsregnskaber. Kbh. 1904 (s. 180-1).

14. Note 1 anf.arb. Enemark, P: Studier, II (s. 221). Repert II 6807.

15. Er muligvis identisk med den lybske hestehandler Hinric Reyse - jf. note 1 anf.arb. Schwetlik (s. 105).

16. jf. note 11 anf.arb.

17. P. Enemark: Kornhandel. KultHist Leks, 9 (sp 147-54).

18. jf. note 1 anf.arb. Schwetlik (s. 97-98), Enemark, P: Studier (s. 174-7).

Da G1 Kbst Lovg, I (s. 83), Quellen Samml, VI (s. 293-8, 304-7).

19. Buchwald, G: Schleswig-Holsteinische Fischereiverhältnisse im XV Jahrhundert. Z Sch-H Gesch 12, 1882 (s. 92).

Stoklund, B: Sildefiske. Danmark. KultHist Leks, 15 (sp. 248-50).

Illing, R: Die Entwicklung der Seefischerei an der Nordseeküste Schleswig-Holsteins. Z Sch-H Gesch, 52, 1923 (s. 1-69). 
Timmermann, U: Riemengeld, Budengeld und andere Abgaben auf Helgoland zu Beginn des 16. Jahrhunderts. Nordfriesisches Jahrb, N.F., 10, 1974 (s. 33-49).

20. jf. note 1 anf.arb. Enemark, P: Studier (s. 102-3).

21. Hansisches Urkundenbuch, Bd 8, 1899 (s. 657-8).

22. Enemark, P: Klede, Handel med klæde. KultHist Leks, 8 (sp. 458-65).

23. Om lærredshandel se - Enemark, P: Lin. Handel med hør. KultHist Leks, 10 (sp. 583-7).

24. Enemark, P: Friesischer Handel zwischen ca. 1500 und 1700. Nordfriesisches Jahrb. 1966 (s. 90-100).

25. Typiske navne er Wunneke Jacobess, Broder Peterss, Pawell Vrese, Paye Vedderss, Junge Haie...

26. Blandt den omfattende litteratur om salt i Slesvig kan nævnes - Gregersen, H.V.: Den Lüneborgske Saltoktroi. 1962.

Lensch, M: Die Salzgewinnung in Nordfriesland. Mitteilungen des Nordfriesischen Vereins. V, 1908/9 (s. 45-68). Prange, W: Ribersalt. Skalk, nr 2, 1982 (s. 28-30).

27. Enemark, P: Ølhandel. Danmark. KultHist Leks, 20 (sp. 707).

28. Danske Middelalderlige Regnskaber, I,1 (s. 308, 915). (=DMR)

29. RArk. Sønderj. fyrsteark. Frederik I. Regnskab over indtægt og udgift for Gottorp amt $1489 / 90$.

30. Enemark, P: Kramhandel. KultHist Leks, 9 (sp. 240-4).

31. For en vurdering af varernes værdi - note 1 anf.arb. Enemark, P: Studier (s. 173-93).

32. Transitruten over Husum - note 1 Anf.arb. Jürgens, A (127-32), Enemark, P: Studier (s. 104-5), Panten, A: Einige Überlegungen zu Flensburgs Verbindungen zum Westen im Mittelalter. Flensburg 700 Jahre. Schriften der Gesellschaft für Flensb. Stadtgesch., 36 (s. 59-68).

33. DMR I,1 (s. 443-64). Galster, G: Fra hertug Frederiks hof. Aarb.f.Nord. Oldkyndighed og Historie. 1967 (s. 21).

34. DMR, I,1 (s. 450-1, 457-8)

35. DMR I,1 (s. 464)

36. Repert II 398637

37. Bruggeman - bl.a. Repert II 10745. Langenborg - bl.a. note 3 anf.arb. LorenzenSchmidt (s. 143).

38. Hansisches Urkundenbuch, Bd 9.1903 (s. 51, nr 102).

39. Da Mag 4 rk,2 (s. 294).

40. Note 1 anf.arb. Schwetlik (s. 152)

41. jf. under Claus Ploch i Repert, Möller, E: Husumer Urkundenbuch 1429-1609. Husum 1939. DMR I,1 (s. 104). Stemann, C.L.E.: Geschichte des öffentlichen und Privat-Rechts. III. Kbh 1867 (s. 190, 197-8).

42. jf. de anf. lensregnskaber, note 19 anf.arb. Buchwald (s. 92). H.v.Rumohr: Dat se bliven ewich tosamende ungedelt. Festschrift. Neumünster 1960 (s. 170).

43. Quellen Samml VI, s. 312.

44. Da Gl Kbst Lovg, II (s. 87 f), Enemark, P: Trelasthande1. Danmark. KultHist Leks, (sp. 589-93).

45. Note 1 anf. arb. Enemark, P: Studier (s. 101-3).

46. Se bl.a. Fischer, O: Nordfriesland. Eiderstedt. Stapelholm. Das Wasserwesen an der der Schleswig-Holsteinischen Nordseeküste, III, 2-3-4. Berlin 1955-8.

47. Henningsen, J: Zur Geschichte eines altfriesischen Bauernhofs in Husum im 15. und 16. Jahrhundert. Jahrb. des Nordfriesischen Vereins. 21, 1934 (s. $80 \mathrm{ff}$ ). 
